\title{
The Specific Uptake of Manganese in the Yeast Candida utilis
}

\author{
By MICHAEL J. PARKIN* AND I. STUART ROSS \\ Department of Biological Sciences, University of Keele, Keele, Staffordshire ST5 5BG, UK
}

(Received 9 December 1985 ; revised 21 February 1986)

\begin{abstract}
Uptake of ${ }^{54} \mathrm{Mn}$ from $10 \mathrm{nM}-\mathrm{Mn}^{2+}$ was shown to be both energy- and $\mathrm{pH}$-dependent. Analysis of the uptake kinetics revealed an apparent half-saturation constant, $K_{\mathrm{t}}$, of $16.4 \mathrm{nM}-\mathrm{Mn}^{2+}$ and a

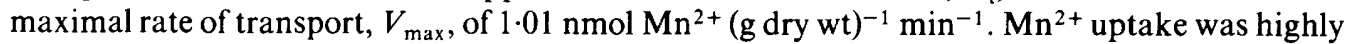
specific, being unaffected by 100 -fold molar excess of $\mathrm{Mg}^{2+}, \mathrm{Zn}^{2+}, \mathrm{Ca}^{2+}, \mathrm{Co}^{2+}, \mathrm{Ni}^{2+}$ and $\mathrm{Cu}^{2+}$; however, uptake was inhibited 30 to $40 \%$ by 1000 -fold molar excess of $\mathrm{Mg}^{2+}, \mathrm{Zn}^{2+}, \mathrm{Ca}^{2+}, \mathrm{Co}^{2+}$ and $\mathrm{Ni}^{2+} . \mathrm{Zn}^{2+}$ competitively inhibited $\mathrm{Mn}^{2+}$ uptake, the $K_{\mathrm{i}}$ value being approximately 500 -fold greater than the $K_{\mathrm{t}}$ for $\mathrm{Mn}^{2+}$. Efflux studies indicated that metabolic exchange of ${ }^{54} \mathrm{Mn}$ occurred to a small extent. Cellular $\mathrm{Mn}^{2+}$ contents remained relatively constant during growth in batch culture. The $\mathrm{Mn}^{2+}$ transport system observed appears to be analogous to the specific metal transport systems reported in bacteria.
\end{abstract}

\section{INTRODUCTION}

Manganese is required by yeasts at trace concentrations for optimal growth and fermentation (Jones \& Greenfield, 1984). A number of reports detailing the accumulation of manganese in yeasts have appeared [Rothstein et al., 1958; Furhmann \& Rothstein, 1968; Okorokov et al., 1977; Parkin \& Ross, $1985 a$; see also Borst-Pauwels (1981) for a review]. $\mathrm{Mn}^{2+}$ is transported by an energy-dependent system primarily responsible for $\mathbf{M g}^{2+}$ transport but which exhibits a broad specificity to other bivalent metal ions including $\mathrm{Co}^{2+}, \mathrm{Zn}^{2+}$ and $\mathrm{Ni}^{2+}$.

If other bivalent trace elements are exclusively taken into cells simply as alternative lowaffinity substrates of the $\mathbf{M g}^{2+}$-transporter, the problem arises as to how a cell might obtain essential elements when, as in normal growth medium, there is a great excess of $\mathrm{Mg}^{2+}$ (often up to 10000 -fold). Silver \& Jasper (1977) suggested that in bacterial systems, for each essential metal ion, there might exist a specific transporter. Indeed, a number of studies in Escherichia coli have demonstrated, in addition to a non-specific $\mathrm{Mg}^{2+}$-transporter (Webb, 1970; Park et al., 1976), the presence of two separate transport systems for $\mathrm{Mg}^{2+}$ (Park et al., 1976) and $\mathrm{Mn}^{2+}$ (Silver \& Kralovic, 1969). These energy-linked transporters exhibited both high affinity and high specificity and were generally detected only in cells grown with very low metal concentrations, which presumably induce such pathways.

Similarly, highly specific active transport systems for $\mathrm{Mn}^{2+}$ have been observed in Bacillus spp. (Silver \& Jasper, 1977), Rhodopseudomonas capsulata (Jasper \& Silver, 1978), Staphylococcus aureus (Perry \& Silver, 1982) and Lactobacillus plantarum (Archibald \& Duong, 1984). In eukaryotic cells, Silver \& Jasper (1977) reported specific manganese transporters in Euglena gracilis and in human $\mathrm{KB}$ cells.

Failla et al. (1976) demonstrated the presence of a highly specific $\mathrm{Zn}^{2+}$ transporter in the yeast Candida utilis. This contrasts with the relatively non-specific bivalent cation transport system observed in Saccharomyces cerevisiae (Borst-Pauwels, 1981). Parkin \& Ross (1985b) suggested that copper influx in $C$. utilis does not occur via a general $\mathbf{M g}^{2+}$ transporter but is facilitated by a separate and much more specific mechanism. These two studies in $C$. utilis used metal concentrations around $1 \mu \mathrm{mol} 1^{-1}$.

Abbreviations: DNP, 2,4-dinitrophenol; CCCP, carbonyl cyanide $m$-chlorophenylhydrazone. 
Previous studies of $\mathrm{Mn}^{2+}$ uptake in Saccharomyces spp. (Norris \& Kelly, 1977; Okorokov et al., 1979; Niewenhuis et al., 1981) have generally used media containing relatively high $\mathbf{M n}^{2+}$ concentrations (in the range $0.2 \mathrm{mM}$ to $3 \mathrm{mM}$ ). Under these conditions saturation of specific highaffinity transport systems may occur thus masking their detection. Hence previous authors, in studying the uptake of $\mathrm{Mn}^{2+}$ in yeasts, may well have observed $\mathrm{Mn}^{2+}$ transport via the lowaffinity $\mathrm{Mg}^{2+}$ transport system. This view is supported by studies of $\mathrm{Mn}^{2+}$ uptake in C. utilis (Parkin \& Ross, 1985a): kinetic analysis of $\mathrm{Mn}^{2+}$ transport from $\mathrm{Mn}^{2+}$ concentrations up to $50 \mu \mathrm{M}$ revealed competitive inhibition by $\mathrm{Mg}^{2+}, \mathrm{Co}^{2+}$ and $\mathrm{Zn}^{2+}$ with similar affinity constants for both $\mathrm{Mn}^{2+}$ and $\mathrm{Mg}^{2+}$.

In the present investigation, using the radionuclide ${ }^{54} \mathrm{Mn}$, the possibility that a specific mechanism exists for the transport of manganese in $C$. utilis was investigated.

\section{METHODS}

Organism and growth. Candida utilis 708 was obtained from the National Collection of Yeast Cultures, Norwich, UK. Cultures were maintained at $4^{\circ} \mathrm{C}$ on MYGP slopes of the following composition $\left(\mathrm{g}^{-1}\right)$ : malt extract (Oxoid), 3 ; yeast extract (Oxoid), 3; glucose, 10; mycological peptone (Oxoid), 5; agar (Oxoid, no. 3), 12. Cells were grown in the medium described by Ross (1977) except that the vitamins were replaced with $0.1 \%$ yeast extract. Medium $(400 \mathrm{ml})$ in a 1 litre shake-flask was inoculated with $0.1 \mathrm{ml}$ of a $24 \mathrm{~h}$ starter culture; subsequent growth was at $30^{\circ} \mathrm{C}$ on an orbital shaker (200 cycles $\left.\mathrm{min}^{-1}\right)$.

Uptake of $\mathrm{Mn}^{2+}$. Cultures were harvested during mid-exponential phase after approximately $18 \mathrm{~h}$ growth when the culture had reached a dry weight of $0.3 \mathrm{mg} \mathrm{ml}^{-1}$ as determined from a curve relating $\mathrm{OD}_{660}$ to dry weight. Dry weights were determined by filtering known volumes of cell suspension through preweighed membrane filters and drying for $16 \mathrm{~h}$ at $105^{\circ} \mathrm{C}$. Cells were collected by centrifugation $(4000 \mathrm{~g}$ for $5 \mathrm{~min}$ ), washed twice with distilled water and resuspended in buffer containing $50 \mathrm{~mm}$-MES and $50 \mathrm{~mm}$-glucose, $\mathrm{pH} 5 \cdot 5$, at $30^{\circ} \mathrm{C}$. The cell density was adjusted to approximately $0.1 \mathrm{mg} \mathrm{m}^{-1}$ so that only a small fraction of the total added $\mathrm{Mn}^{2+}$ was taken up during the assay. Cells were allowed to equilibrate in this medium for $30 \mathrm{~min}$ before adding $\mathrm{Mn}^{2+}$. For experiments measuring ${ }^{54} \mathrm{Mn}$ accumulation in batch culture, the medium of Failla et al. (1976) was used, supplemented with trace elements as follows $\left(\mathrm{gl}^{-1}\right): \mathrm{MgSO}_{4} .7 \mathrm{H}_{2} \mathrm{O}, 0.74 ; \mathrm{CaCl}_{2} .6 \mathrm{H}_{2} \mathrm{O}, 0.25 ; \mathrm{FeSO}_{4} .7 \mathrm{H}_{2} \mathrm{O}, 0.005 ; \mathrm{ZnSO}_{4} .7 \mathrm{H}_{2} \mathrm{O}$, $0.00175 ; \mathrm{CuSO}_{4} .5 \mathrm{H}_{2} \mathrm{O}, 0.0001$. The inhibitors carbonyl cyanide $m$-chlorophenylhydrazone (CCCP) and 2,4dinitrophenol (DNP) were added $15 \mathrm{~min}$ before the $\mathrm{Mn}^{2+}$. Solutions of the chloride salts of $\mathrm{Mg}^{2+}, \mathrm{Zn}^{2+}, \mathrm{Co}^{2+}$, $\mathrm{Cu}^{2+}, \mathrm{Ni}^{2+}$ and $\mathrm{Ca}^{2+}$ were added 1 min before the addition of $\mathrm{Mn}^{2+}$ to give a final volume of $20 \mathrm{ml}$ in $100 \mathrm{ml}$ flasks on a shaking water bath at $30^{\circ} \mathrm{C} .{ }^{54} \mathrm{MnCl}_{2}$ [Amersham; $0.275 \mu \mathrm{Ci} \mathrm{ml}^{-1}\left(10.175 \mathrm{kBq} \mathrm{ml}^{-1}\right)$ ] was added to give a final ${ }^{54} \mathrm{Mn}$ concentration of $10 \mathrm{~nm}$ unless otherwise stated. At intervals, $1 \mathrm{ml}$ samples were removed and filtered through $0.45 \mu \mathrm{m}$ filters (Whatman), and then washed rapidly with $10 \mathrm{ml}$ of a chilled solution of $100 \mu \mathrm{M}$ nonradioactive $\mathrm{MnCl}_{2}$ in order to remove ${ }^{54} \mathrm{Mn}^{2+}$ adsorbed on to the cell walls (Borst-Pauwels, 1981). Radioactivity on the filters was then counted in a Packard Auto-Gamma scintillation spectrometer. All glassware used in uptake experiments was acid-washed to minimize metal contamination. Chemicals used were of high-purity AnalaR grade; MES and CCCP were obtained from Sigma.

\section{RESULTS}

\section{Energy dependence of uptake}

$\mathrm{Mn}^{2+}$ uptake by cells harvested from exponentially growing cultures proceeded almost linearly at $30^{\circ} \mathrm{C}$ in the presence of glucose (Fig. 1). However, at $4{ }^{\circ} \mathrm{C}$ or in the absence of glucose, uptake was not observed. Similarly, in the presence of the metabolic inhibitors CCCP and DNP, no uptake occurred. Thus it appears that $\mathrm{Mn}^{2+}$ transport is an energy-requiring process. Non-specific binding of the metal to anionic species on the cell surfaces occurred almost instantaneously, reaching about $7 \%$ of the total $\mathrm{Mn}^{2+}$ bound after $20 \mathrm{~min}$. This may well reflect the efficacy of the cell washing procedure when compared to a value of nearly $20 \% \mathrm{Mn}^{2+}$ bound in $20 \mathrm{~min}$ in the same species using $2 \mathrm{mM}-\mathrm{CaCl}_{2}$ as a washing solution (Parkin \& Ross, 1985b).

\section{$p H$ dependence of uptake}

$\mathrm{Mn}^{2+}$ transport was highly dependent upon the $\mathrm{pH}$ of the suspending medium. At $\mathrm{pH} 5.5$ cells accumulated $5.65 \pm 0.36 \mathrm{nmol} \mathrm{Mn}^{2+}\left(\mathrm{g}\right.$ dry wt) ${ }^{-1}$ over $20 \mathrm{~min}$ from $10 \mathrm{nM}-\mathrm{Mn}^{2+}$ (values given are the mean $\pm \mathrm{SE}$ of three experiments). As the $\mathrm{pH}$ was decreased to $3.0 \mathrm{Mn}^{2+}$ uptake decreased 


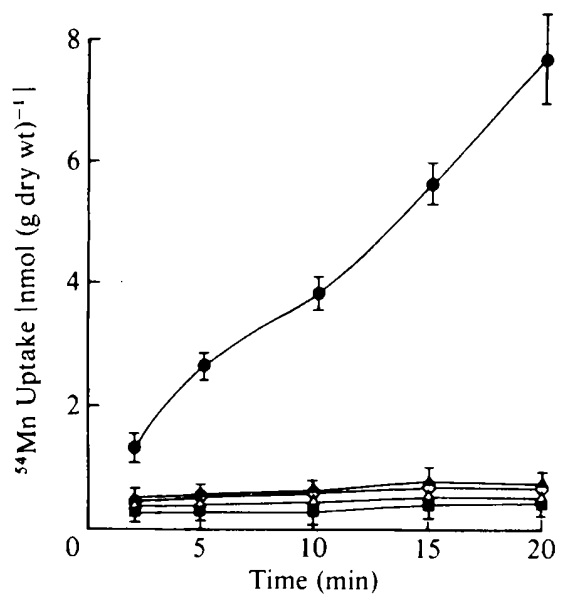

Fig. 1

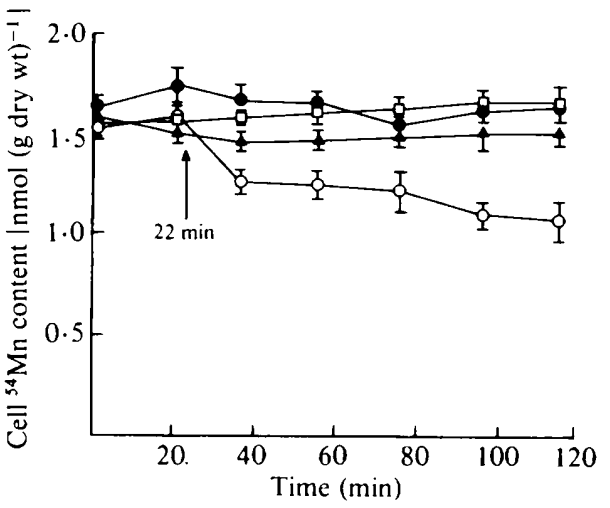

Fig. 2

Fig. 1. Energy dependence of $\mathrm{Mn}^{2+}$ uptake. $\mathrm{Mn}^{2+}$ accumulation from $10 \mathrm{nM}-\mathrm{Mn}^{2+}$ in the presence $(O$, $\Delta, \square, O)$ and absence $(\Delta)$ of glucose, and in the presence of $100 \mu \mathrm{M}-\mathrm{CCCP}(\square)$ or $2 \mathrm{mM}-\mathrm{DNP}(\mathrm{O}) ; \boldsymbol{\Delta}$, uptake at $4^{\circ} \mathrm{C}$. Values shown are the mean \pm SE of three experiments (for clarity, only the maximum SE bars have been included for uptake in the absence of glucose, at $4^{\circ} \mathrm{C}$ and in the presence of CCCP or DNP).

Fig. 2. $\mathrm{Mn}^{2+}$ efflux from $\mathrm{Mn}^{2+}$ preloaded cells. $\mathrm{Mn}^{2+}$-loaded cells were suspended at a density of $0.5 \mathrm{mg}$ dry wt ml $\mathrm{m}^{-1}$ in $\mathrm{Mn}^{2+}$-free buffer containing $50 \mathrm{~mm}$-glucose and incubated at $30^{\circ} \mathrm{C}$ in the absence $(\square, O)$ and presence $(O, \Delta)$ of $100 \mu \mathrm{M}-\mathrm{CCCP}$, with the addition of $1 \mathrm{~mm}-\mathrm{MnCl}_{2}$ (arrow) at $22 \min (\Lambda, O)$. Values shown are the mean \pm SE of three experiments.

\section{Table 1. Effect of divalent cation competition on $\mathrm{Mn}^{2+}$ uptake}

Values shown (mean \pm SE of three experiments) are for uptake after 20 min from $10 \mathrm{nM}-\mathrm{Mn}^{2+}$ in the presence of competing cations as indicated. The control value for uptake in the absence of any competing cation was $5 \cdot 16 \pm 0.38 \mathrm{nmol} \mathrm{Mn}{ }^{2+}(\mathrm{g} \text { dry wt })^{-1}$. ND, Not determined.

$\begin{array}{ccc}\text { Competing cation } & \begin{array}{c}\mathrm{Mn}^{2+} \text { uptake (percentage of comtrol) in the presence of } \\ \text { (100-fold excess) }\end{array} & \begin{array}{c}10 \mu \mathrm{M} \text { Competing cation } \\ (1000 \text {-fold excess) }\end{array} \\ \mathrm{Mg}^{2+} & 90.6 \pm 3.7 & 73.6 \pm 13.8 \\ \mathrm{Zn}^{2+} & 96.4 \pm 13.0 & 57.4 \pm 5.7 \\ \mathrm{Co}^{2+} & 108.7 \pm 14.6 & 70.3 \pm 9.8 \\ \mathrm{Ni}^{2+} & 107.5 \pm 13.4 & 61.8 \pm 3.5 \\ \mathrm{Ca}^{2+} & 98.5 \pm 9.0 & 91.9 \pm 8.5 \\ \mathrm{Cu}^{2+} & 102.6 \pm 1.4 & \mathrm{ND}\end{array}$

sharply to $0.29 \pm 0.02 \mathrm{nmol} \mathrm{Mn}^{2+}(\mathrm{g} \text { dry wt })^{-1}$. At $\mathrm{pH} 7 \cdot 0$ and above a massive increase to over $15 \mathrm{nmol} \mathrm{Mn}{ }^{2+}(\mathrm{g} \text { dry wt) })^{-1}$ cells was recorded. It is probable that at these high $\mathrm{pH}$ values insoluble complexes of manganese hydroxide are precipitated on the cell surfaces.

\section{Specificity of uptake}

Table 1 shows the effect of bivalent cation competition on ${ }^{54} \mathrm{Mn}$ uptake. Oxygen uptake studies revealed that, with the exception of $\mathrm{Cu}^{2+}$ at $10 \mu \mathrm{M}$, none of the ions were toxic at the concentrations used here (data not shown). Uptake was unaffected by 100 -fold molar excess of other bivalent cations; in the presence of 1000 -fold excess of $\mathrm{Mg}^{2+}, \mathrm{Zn}^{2+}, \mathrm{Co}^{2+}$ and $\mathrm{Ni}^{2+}$ uptake was still 57 to $74 \%$ of the original value, while 1000 -fold excess $\mathrm{Ca}^{2+}$ exerted a somewhat less inhibitory effect. 


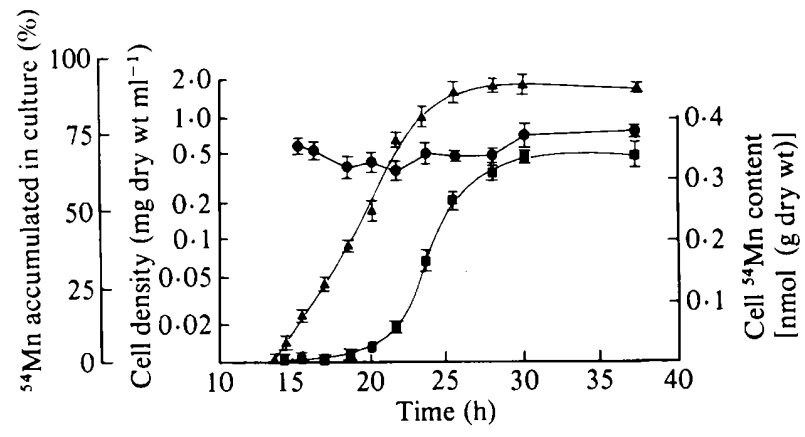

Fig. ${ }^{3 .}{ }^{54} \mathrm{Mn}$ accumulation during growth in batch culture. $\Delta$, Cell density of culture; $\square$, total ${ }^{54} \mathrm{Mn}$ accumulated by culture; $O$, cellular ${ }^{54} \mathrm{Mn}$ content. Values shown are the mean \pm SE of three experiments.

\section{Uptake kinetics}

In studies of the uptake of metal ions from very low external concentrations, it is important to assess the extent to which metal complexation to glassware and media components may affect subsequent kinetic evaluations. The MES buffer chosen has negligible metal-complexing capacity (Good et al., 1966) and has been previously used in metal uptake experiments (Parkin \& Ross, 1985b). Prolonged uptake experiments, using a high cell density suspension, recovered almost $100 \%$ of added radioactivity, demonstrating that virtually all the ${ }^{54} \mathrm{Mn}$ was available to the cells (data not shown).

The uptake kinetics were determined from the linear rates of uptake over $20 \mathrm{~min}$ from $\mathrm{Mn}^{2+}$ concentrations in the range 2.5 to $50 \mathrm{nM}$. If the mean data of three separate experiments are plotted by the Lineweaver-Burk method, and the resultant straight line is fitted by the leastsquares method, the intercepts on the $y$ - and $x$-axes give estimates of the maximal rate of transport, $V_{\max }$, and apparent half-saturation constant, $K_{\mathrm{t}}$, respectively. The degree of uncertainty in these estimates can be quantified by calculating the standard error of estimate (SEE) giving a mean value for $K_{\mathrm{t}}$ of $16.4 \mathrm{nM}-\mathrm{Mn}^{2+}$ (range 12.3 to $24.4 \mathrm{nM}$ ) and for $V_{\max }$ of $1.01 \mathrm{nmol}$ (g dry wt) ${ }^{-1}$ [range 0.76 to $1.50 \mathrm{nmol}$ (g dry wt) ${ }^{-1} \min ^{-1}$ ]. Since $\mathrm{Zn}^{2+}$, at $10 \mu \mathrm{M}$, appeared to inhibit uptake by over $40 \%, \mathrm{Mn}^{+}$uptake was examined over the range 2.5 to $50 \mathrm{nM}$ in the presence of $100 \mu \mathrm{M}-\mathrm{Zn}^{2+}$. The initial uptake rates were plotted as before to determine the nature of this inhibition (data not shown). Inhibition was competitive giving an inhibition constant $\left(K_{\mathrm{i}}\right)$ value of $8.0 \mu \mathrm{M}$ (range 7.3 to $8.9 \mu \mathrm{M}$ ) as calculated from the slope of the line showing inhibition.

$$
{ }^{54} \mathrm{Mn} \text { efflux }
$$

To investigate the possibility of a metabolic efflux system cells were pre-loaded with ${ }^{54} \mathrm{Mn}$ and resuspended in ${ }^{54} \mathrm{Mn}$-free buffer containing glucose. When $1 \mathrm{mM}-\mathrm{MnCl}_{2}$ was added at $22 \min 25 \%$ of the cellular $\mathrm{Mn}^{2+}$ was released into the medium during the following $13 \mathrm{~min}$. This release was markedly reduced in the presence of CCCP (Fig. 2).

\section{${ }^{54} \mathrm{Mn}$ accumulation during growth in batch culture}

This is shown in Fig. 3. The cell $\mathrm{Mn}^{2+}$ content remained fairly constant throughout the growth period. It should be noted that the medium was closely maintained at $\mathrm{pH} 6.0$ during this time by the addition of $\mathrm{KOH}$ or $\mathrm{HCl}$. Failure to do so resulted in a drop in $\mathrm{pH}$ to 3.8 over $3.5 \mathrm{~h}$ during late-exponential phase coupled with a $50 \%$ reduction of the cell $\mathrm{Mn}^{2+}$. This dilution effect may well be due to reduced $\mathrm{Mn}^{2+}$ uptake under low $\mathrm{pH}$ conditions during culture growth.

\section{DISCUSSION}

Dependence upon a cellular energy source is a fairly well-documented feature of metal cation transport systems in micro-organisms (Norris \& Kelly, 1977; Ross, 1977; Borst-Pauwels, 1981 ; 
Gadd \& White, 1985). The lack of ${ }^{54} \mathrm{Mn}$ influx in the presence of the uncoupling agents CCCP and DNP is indicative of a metabolically dependent process. In our system, at a cell density of $10^{7}$ cells $\mathrm{ml}^{-1}$, occupying a packed cell volume of approximately $0 \cdot 1 \%(\mathrm{v} / \mathrm{v})$ of the medium (assuming intercellular spaces to be minimal), $10^{7}$ cells took up $1.53 \times 10^{-3} \mathrm{nmol}$ during $20 \mathrm{~min}$ incubation in $10 \mathrm{nM}^{-54} \mathrm{Mn}$. Assuming all cellular $\mathrm{Mn}^{2+}$ to be in an unbound, ionic form, this represents an uphill transport concentration gradient of approximately 180:1 (inside: outside). However, it is unlikely that all the $\mathrm{Mn}^{2+}$ is present in an osmotically free form. Okorokov et al. (1977) estimated that $78 \%$ of the total $\mathrm{Mn}^{2+}$ was bound to cellular components. Other reports suggest that bivalent cations may be compartmentalized within cell vacuoles and sequestered to polyphosphates (Borst-Pauwels, 1981). $\mathrm{Mn}^{2+}$ uptake, at the $\mathrm{Mn}^{2+}$ concentrations studied, appears to be via a highly specific mechanism, unlike the low affinity divalent cation transporter previously observed (Parkin \& Ross, 1985a). The degree of cation specificity is not as great as that observed by Silver et al. (1970) for $\mathrm{Mn}^{2+}$ transport in $E$. coli, which was largely unaffected by $10^{6}$-fold molar excess of $\mathrm{Mg}^{2+}, \mathrm{Ca}^{2+}$ or $\mathrm{Sr}^{2+}$. Nevertheless the present yeast system exhibits considerable discrimination for $\mathrm{Mn}^{2+}$ in the presence of 1000 -fold excess of $\mathrm{Mg}^{2+}, \mathrm{Zn}^{2+}, \mathrm{Co}^{2+}$, $\mathrm{Ni}^{2+}$ or $\mathrm{Ca}^{2+}$.

As far as we are aware, the kinetic data available in the literature for $\mathrm{Mn}^{2+}$ uptake in yeasts pertains to uptake via the $\mathrm{Mg}^{2+}$ transporter and, as would be expected for such a system, gives affinity constants several orders of magnitude greater than the $K_{1}$ value of $16.4 \mathrm{nM}-\mathrm{Mn}^{2+}$ observed in this study. The only comparable affinity constants calculated for micronutrient transport systems in yeasts are $0.36 \mu \mathrm{M}-\mathrm{Zn}^{2+}$ (Lawford et al., 1980) and $1.3 \mu \mathrm{M}-\mathrm{Zn}^{2+}$ (Failla et al., 1976) for $\mathrm{Zn}^{2+}$-specific uptake in $C$. utilis. However, in bacteria, $K_{\mathrm{t}}$ values for $\mathrm{Mn}^{2+}$-specific transport ranging from 0.05 to $2 \mu \mathrm{M}-\mathrm{Mn}^{2+}$ have been reported (Silver \& Kralovic, 1969; Silver, 1978; Archibald \& Duong; 1984). The maximal $\mathrm{Mn}^{2+}$ uptake rate in our strain of $C$. utilis $\left[1.01 \mathrm{nmol}(\mathrm{g} \text { dry wt) })^{-1} \mathrm{~min}^{-1}\right]$ is somewhat lower than in previously described systems (Silver, 1978), and this may reflect a difference in $\mathrm{Mn}^{2+}$ requirements between the various cell types or may simply be due to variations in experimental techniques. $\mathrm{Zn}^{2+}$ competitively inhibited $\mathrm{Mn}^{2+}$ uptake; however, the inhibitory constant, $K_{\mathrm{i}}$, was some 500 times greater than the $K_{\mathrm{t}}$ for $\mathrm{Mn}^{2+}$. It is probable that the other cations might also exert some reduced competitive effect as it is unlikely that the specificity will be complete in a mechanism of this type. Silver et al. (1970) demonstrated competitive inhibition of $\mathrm{Mn}^{2+}$ transport by both $\mathrm{Co}^{2+}$ and $\mathrm{Fe}^{2+}$ in $E$. coli whilst $\mathrm{Cd}^{2+}$ has also been shown to inhibit competitively $\mathrm{Mn}^{2+}$ uptake in Lactobacillus plantarum (Archibald \& Duong, 1984) and Bacillus subtilis (Laddaga et al., 1985). $\mathrm{Cd}^{2+}$ was not included in this study as yeasts have no essential requirement for this ion and a number of deleterious effects of $\mathrm{Cd}^{2+}$ on cells have been reported (Gadd \& Mowll, 1983; Grafl \& Schwantes, 1983; Jones \& Greenfield, 1984).

Energy-linked systems for $\mathrm{Mg}^{2+}$ efflux exist in $E$. coli (Lusk \& Kennedy, 1969) and $\mathrm{Mn}^{2+}$ and $\mathrm{Sr}^{2+}$ egress has been observed in $S$. cerevisiae (Nieuwenhuis et al., 1981). Our results suggest that a metabolism-dependent exchange of ${ }^{54} \mathrm{Mn}$ occurs, albeit to a relatively small extent. It has been suggested that displacement of the metal ions from intracellular sites may occur (Jasper \& Silver, 1977) and this possibility is not precluded.

Fluctuations in cellular metal levels during batch growth have been observed for $\mathrm{Zn}^{2+}$ in $C$. utilis (Failla \& Weinberg, 1977) and $\mathrm{Cu}^{2+}$ in E. coli (Baldry \& Dean, 1980). Both studies demonstrated an uptake peak during late-exponential phase, the former study also demonstrating rapid uptake during the lag phase of growth. However, $\mathrm{Mn}^{2+}$ uptake in C. utilis does not appear to be under such regulation, the cell $\mathrm{Mn}^{2+}$ level remaining constant around $0.35 \mathrm{nmol}$ ( $\mathrm{g}$ dry wt $)^{-1}$ in our experiments. Attempts to culture cells in the medium described by Failla \& Weinberg (1977) resulted in a pH drop to 3.8 during late-exponential phase of growth. Under these conditions $\mathrm{Mn}^{2+}$ uptake would be severely limited.

Thus in conclusion, there exists in $C$. utilis a $\mathrm{Mn}^{2+}$ transport system which is energydependent, substrate-specific and of high affinity. This system is only detected at submicromolar concentrations of the metal and is independent of the non-specific $\mathbf{M g}^{2+}$ transporter (Parkin \& Ross, 1985b). 
The authors gratefully acknowledge the Science and Engineering Research Council for the receipt of a studentship for M.J.P.

\section{REFERENCES}

ARChibald, F. S. \& Duong, M. (1984). Manganese acquisition by Lactobacillus plantarum. Journal of Bacteriology 158, 1-8.

BaldRy, M. G. C. \& Dean, A. C. R. (1980). Copper accumulation by Escherichia coli strain FE 12/5. 1 . Uptake during batch culture. Microbios Letters 15, 83-87.

Borst-Pauwels, G. W. F. H. (1981). Ion uptake in yeast. Biochimica et biophysica acta 650, 88-127.

Failla, M. L. \& WeinberG, E. D. (1977). Cyclic accumulation of zinc by Candida utilis during growth in batch culture. Journal of General Microbiology 99 , $85-97$.

Failla, M. L., Benedict, C. D. \& Weinberg, E. D. (1976). Accumulation and storage of $\mathrm{Zn}^{2+}$ by Candida utilis. Journal of General Microbiology 94, 23-26.

FurhmanN, G. F. \& Rothstein, A. (1968). The transport of $\mathrm{Zn}, \mathrm{Co}$ and $\mathrm{Ni}$ into yeast cells. Biochimica et biophysica acta 163, 325-330.

GADD, G. M. \& Mowll, J. L. (1983). The relationship between cadmium uptake, potassium release and viability in Saccharomyces cerevisiae. FEMS Microbiology Letters 16, 45-48.

GADD, G. M. \& WHITE, C. (1985). Copper uptake by Penicillium ochro-chloron: influence of $\mathrm{pH}$ on toxicity and demonstration of energy-dependent copper influx using protoplasts. Journal of General Microbiology 131, 1875-1879.

GoOD, N. E., WINGET, G. D., WINTER, W., Connolly, T. N., Izawa, S. \& Singh, R. M. M. (1966). Hydrogen ion buffers for biological research. Biochemistry 5, 467-477.

Grafl, H. J. \& Schwantes, H. O. (1983). The effects of cadmium, zinc, lead and mercury on respiration and fermentation of Saccharomyces cerevisiae. Angewandte Botanik 57, 31-44.

JASPER, P. \& SILVER, S. (1977). Magnesium transport in microorganisms. In Microorganisms and Minerals, pp. 7-47. Edited by E. D. Weinburg. New York: Marcel Dekker.

JASPER, P. \& SILVER, S. (1978). Divalent cation transport systems of Rhodopseudomonas capsulata. Journal of Bacteriology 133, 1323-1328.

Jones, R. P. \& GREenfield, P. F. (1984). A review of yeast ionic nutrition, part $1:$ growth and fermentation requirements. Process Biochemistry 19, 48-62.

LadDaga, R. A., Bessen, R. \& Silver, S. (1985). Cadmium-resistant mutant of Bacillus subtilis 168 with reduced cadmium transport. Journal of Bacteriology 162, 1106-1110.

LAWFORD, H. G., PIK, J. R., LAWFORd, G. R., Williams, T. \& Kligerman, A. (1980). Hyperaccumulation of zinc by zinc-depleted Candida utilis grown in chemostat culture. Canadian Journal of Microbiology 26, 71-76.

LuSK, J. E. \& KENNEDY, E. P. (1969). Magnesium transport in Escherichia coli. Journal of Biological Chemistry 244, 1653-1655.
Nieuwenhuis, B. J. W. M., Weijers, C. A. G. M. \& Borst-Pauwels, G. W. F. H. (1981). Uptake and accumulation of $\mathrm{Mn}^{2+}$ and $\mathrm{Sr}^{2+}$ in Saccharomyces cerevisiae. Biochimica et biophysica acta 649, 83-88.

NorRIS, P. R. \& KeLly, D. P. (1977). Accumulation of cadmium and cobalt by Saccharomyces cerevisiae. Journal of General Microbiology 99, 317-324.

OKorokov, L. A., LichKo, L. P., KadomtseVA, V. M., Kholodenko, V. P., Titovski, V. P. \& Kulaev, I. S. (1977). Energy dependent transport of manganese into yeast cells and distribution of accumulated ions. European Journal of Biochemistry 75, 373-377.

OKorokov, L. A., Kadomtseva, V. M. \& Titovski, V. I. (1979). Transport of manganese into Saccharomyces cerevisiae. Folia microbiologia 24, 240-246.

PARK, M. H., WONG, B. B. \& LuSK, J. E. (1976). Mutants in three genes affecting transport of magnesium in Escherichia coli: genetics and physiology. Journal of Bacteriology 126, 1096-1103.

PARKIN, M. J. \& Ross, I. S. (1985a). The transport and accumulation of manganese in the yeast, Candida utilis. In Heavy Metals in the Environment (Proceedings of the International Conference, Athens, Greece), vol. 2, pp. 289-291. Edited by T. D. Lekkas. Edinburgh: CPC Consultants.

PARKIN, M. J. \& Ross, I. S. (1985b). Uptake of copper and manganese by the yeast, Candida utilis. Microbios Letters 29, 115-120.

Perry, R. D. \& Silver, S. (1982). Cadmium and manganese transport in Staphylococcus aureus membrane vesicles. Journal of Bacteriology 150, 973-976.

Ross, I. S. (1977). Effect of glucose on copper uptake and toxicity in Saccharomyces cerevisiae. Transactions of the British Mycological Society 69, 77-81.

Rothstein, A., Hayes, A., Jennings, D. \& HoOper, D. (1958). The active transport of $\mathrm{Mg}^{2+}$ and $\mathrm{Mn}^{2+}$ into the yeast cell. Journal of General Physiology 41, 585-594.

SILVER, S. (1978). Transport of cations and anions. In Bacterial Transport, pp. 222-324. Edited by B. P. Rosen. New York: Marcel Dekker.

SILVER, S. \& J ASPER, P. (1977). Manganese transport in microorganisms. In Microorganisms and Minerals, pp. 105-149. Edited by E. D. Weinberg. New York: Marcel Dekker.

Silver, S. \& Kralovic, M. L. (1969). Manganese accumulation by Escherichia coli: evidence for a specific transport system. Biochemical and Biophysical Research Communications 34, 640-645.

Silver, S., Johnseine, P. \& King, K. (1970). Manganese active transport in Escherichia coli. Journal of Bacteriology 104, 1299-1306.

WEBB, M. (1970). Interrelationships between the utilisation of magnesium and the uptake of other bivalent cations by bacteria. Biochimica et biophysica acta 222, 428-439. 